\title{
IMPLEMENTASI GAMIFIKASI BERBANTU MEDIA KAHOOT UNTUK MENINGKATKAN AKTIVITAS BELAJAR, MOTIVASI BELAJAR, DAN HASIL BELAJAR JURNAL PENYESUAIAN SISWA KELAS X AKUNTANSI 3 DI SMK KOPERASI YOGYAKARTA TAHUN AJARAN 2018/2019
}

\section{IMPLEMENTATION OF GAMIFICATION WITH KAHOOT TO IMPROVE LEARNING ACTIVITY, LEARNING MOTIVATION, AND LEARNING OUTCOMES OF ADJUSTING JOURNAL ENTRY AT CLASS X ACCOUNTING 3 STUDENTS OF SMK KOPERASI YOGYAKARTA IN THE ACADEMIC YEAR OF 2018/2019}

\author{
Oleh: \\ Serly Wardana \\ Prodi Pendidikan Akuntansi Universitas Negeri Yogyakarta \\ sherlywardana@gmail.com \\ Endra Murti Sagoro \\ Staf Pengajar Jurusan Pendidikan Akuntansi Universitas Negeri Yogyakarta
}

\begin{abstract}
Abstrak
Penelitian ini bertujuan untuk (1) meningkatkan Aktivitas Belajar Siswa Kelas X Akuntansi 3 di SMK Koperasi Yogyakarta melalui penerapan Gamifikasi Berbantu Media Kahoot; (2) meningkatkan Motivasi Belajar Siswa Kelas X Akuntansi 3 di SMK Koperasi Yogyakarta melalui penerapan Gamifikasi Berbantu Media Kahoot; (3) meningkatkan Hasil Belajar Jurnal Penyesuaian Siswa Kelas X Akuntansi 3 di SMK Koperasi Yogyakarta melalui penerapan Gamifikasi Berbantu Media Kahoot. Penelitian ini merupakan Penelitian Tindakan Kelas (PTK) yang dilakukan sebanyak 2 siklus yang terdiri dari perencanaan, pelaksanaan tindakan, observasi dan refleksi. Hasil penelitian ini menunjukkan peningkatan Aktivitas Belajar sebesar $14,31 \%$, dapat dilihat dari kenaikan persentase rata-rata dari $64,68 \%$ menjadi 78,99\%. Peningkatan Motivasi Belajar sebesar 9,22\%, dapat dilihat dari kenaikan persentase rata-rata dari 69,88\% menjadi 79,10\%. Peningkatan Hasil Belajar sebesar 27,13, dapat dilihat dari kenaikan nilai rata-rata pra penelitian dan post-test siklus II, dan persentase ketuntasan belajar dari $12,50 \%$ menjadi $82,61 \%$ yang berarti mengalami peningkatan sebesar $70,11 \%$.
\end{abstract}

Kata kunci: Gamifikasi, Kahoot, Aktivitas Belajar, Motivasi Belajar, Hasil Belajar

\section{Abstract}

This study aims to (1) improve student Learning Activity at Class X Accounting 3 in SMK Koperasi Yogyakarta through the implementation of the Gamification with Kahoot; (2) improve Learning Motivation at Class X Accounting 3 in SMK Koperasi Yogyakarta through the implementation of the Gamification with Kahoot; (3) improve Learning Outcomes of Adjusting Journal Entry at Class X Accounting 3 in SMK Koperasi Yogyakarta through the implementation of the Gamification with Kahoot. This study is a Classroom Action Research (CAR) conducted in 2 cycles, which are planning, implementing, observing, and reflecting. The result showed the Learning Activity increased by 14,31\%, which can be seen from the increase in average percentage from 64,68\% to 78,99\%. The Learning Motivation increased by $9,22 \%$, which can be seen from the increase in percentage of average of $69,88 \%$ to 
79,10\%. While the Learning Outcomes increased by 27,13, which can be seen from the increase in average scores from pre-study and post-test II, and the percentage of learning completeness from 12,50\% to 82,61\% which means increased 70,11\%.

Keywords: Gamification, Kahoot, Learning Activity, Learning Motivation, Learning Outcomes

\section{PENDAHULUAN}

Pendidikan merupakan salah satu langkah penting bagi seseorang untuk meningkatkan kualitas hidupnya. Demi mewujudkan manusia yang berkualitas, diperlukan pendidikan yang berkualitas pula. Pendidikan yang berkualitas diperoleh dengan adanya proses pembelajaran yang baik. Proses pembelajaran dapat ditunjang dengan adanya fasilitas, lingkungan, dan model pembelajaran yang mendukung.

Model pembelajaran dengan komunikasi satu arah mengakibatkan siswa tidak dilibatkan secara aktif dalam proses pembelajaran sehingga siswa kurang terlibat secara dominan dalam proses pembelajaran. Siswa yang tidak dilibatkan secara aktif akan mudah merasa bosan dan cenderung kurang termotivasi untuk belajar. Kurang aktif dan kurang adanya motivasi pada diri siswa pada akhirnya akan mengakibatkan Hasil Belajar yang kurang memuaskan.

Permasalahan seperti Aktivitas Belajar, Motivasi Belajar dan Hasil Belajar menjadi permasalahan yang sering kali muncul pada sekolah, salah satunya di SMK Koperasi Yogyakarta. SMK Koperasi Yogyakarta merupakan sekolah menengah kejuruan swasta di bawah naungan Yayasan Pembina Pendidikan Koperasi Yogyakarta. Berdasarkan observasi yang telah dilaksanakan pada 8 dan 15 Januari 2019 di kelas $\mathrm{X}$ Akuntansi 3 Tahun Ajaran 2018/2019 di SMK Koperasi Yogyakarta ditemukan tiga masalah pada kelas tersebut. Permasalahan yang terjadi pada kelas tersebut adalah rendahnya Aktivitas Belajar, rendahnya Motivasi Belajar, dan rendahnya Hasil Belajar.

Faktor yang menyebabkan rendahnya Aktivitas Belajar, Motivasi Belajar, dan Hasil Belajar siswa kelas X Akuntansi 3 SMK Koperasi Yogyakarta adalah proses belajar mengajar yang masih belum maksimal. Untuk memaksimalkan proses belajar mengajar diperlukan model pembelajaran yang tepat agar siswa dapat aktif, termotivasi dan memiliki hasil belajar yang baik. Penerapan model pembelajaan yang kurang sesuai akan menyebabkan siswa merasa bosan dan kurang tertarik untuk mengikuti dan memahami materi yang disajikan oleh guru. Hal ini terbukti pada saat diterapkan model pembelajaran ceramah oleh guru siswa cenderung bosan dan kurang memperhatikan apa yang guru sampaikan di depan kelas. Hal ini menyebabkan Hasil Belajar pada bidang kognitif belum mencapai target Kriteria Ketuntasan Minimal (KKM) yang ditetapkan sekolah yakni sebesar 75 untuk mata pelajaran Akuntansi Dasar. Permasalahan ini terjadi pada mata pelajaran Akuntansi Dasar yang mana merupakan dasar utama dari pelajaran akuntansi yang lain.

Aktivitas Belajar di dalam kelas yang rendah ditunjukkan dengan beberapa siswa nampak tidur, mengobrol dengan teman di sebelahnya, dan bermain gadget. Rendahnya Aktivitas Belajar tersebut didukung dengan adanya data pra penelitian sebagai berikut.

Tabel 1. Kategori Skor Aktivitas Belajar Pra Penelitian

\begin{tabular}{|l|c|l|}
\hline No & Interval & \multicolumn{1}{c|}{ Kategori } \\
\hline 1 & $16,2<\mathrm{x}<18$ & Sangat Baik \\
\hline 2 & $14,4<\mathrm{x}<16,2$ & Baik \\
\hline 3 & $12,6<\mathrm{x}<14,4$ & Sedang \\
\hline 4 & $10,8<\mathrm{x}<12,6$ & Rendah \\
\hline 5 & $9<\mathrm{x}<10,8$ & Sangat Rendah \\
\hline
\end{tabular}

Perolehan skor rata-rata Aktivitas Belajar pada pra penelitian adalah 12,29. Perolehan skor rata-rata Aktivitas Belajar pra penelitian dapat dilihat pada lampiran 
1.4. Berdasarkan tabel 1 di atas dapat diketahui bahwa dengan perolehan skor ratarata sebesar 12,29 maka dapat disimpulkan bahwa Aktivitas Belajar pada kelas tersebut termasuk dalam kategori rendah. Berdasarkan data tersebut dapat disimpulkan bahwa terdapat permasalahan pada kelas $\mathrm{X}$ Akuntansi 3 SMK Koperasi Yogyakarta yakni Aktivitas Belajar yang rendah.

Permasalahan lainnya juga ditemukan yakni Motivasi Belajar siswa pada kelas X Akuntansi 3 masih tergolong rendah. Rendahnya Motivasi Belajar tersebut ditunjukkan selama proses pembelajaran berlangsung siswa kurang bersemangat dan tidak aktif dalam menjalankan pembelajaran. Rendahnya Motivasi Belajar didukung dengan data pra penelitian sebagai berikut:

Tabel 2. Kategori Skor Motivasi Belajar Pra Penelitian

\begin{tabular}{|l|c|l|}
\hline No & Interval & \multicolumn{1}{|c|}{ Kategori } \\
\hline 1 & $73,8<\mathrm{x}<79$ & Sangat Baik \\
\hline 2 & $68,6<\mathrm{x}<73,8$ & Baik \\
\hline 3 & $63,4<\mathrm{x}<68,6$ & Sedang \\
\hline 4 & $58,2<\mathrm{x}<63,4$ & Rendah \\
\hline 5 & $53<\mathrm{x}<58,2$ & Sangat Rendah \\
\hline
\end{tabular}

Perolehan skor rata-rata Motivasi Belajar pada pra penelitian adalah 61,63. Perolehan skor rata-rata Motivasi Belajar pra penelitian dapat dilihat pada lampiran 1.5. Berdasarkan tabel 2 di atas dapat diketahui bahwa dengan perolehan skor rata-rata sebesar 61,63 maka dapat disimpulkan bahwa Motivasi Belajar pada kelas tersebut termasuk dalam kategori rendah. Berdasarkan data tersebut dapat disimpulkan bahwa terdapat permasalahan pada kelas X Akuntansi 3 SMK Koperasi Yogyakarta yakni Motivasi Belajar yang rendah.

Hasil Belajar yang belum memenuhi target dapat dilihat dari nilai rata-rata Ulangan Harian (UH) yang masih tergolong rendah. Hal ini juga didukung dengan data pra penelitian sebagai berikut:
Tabel 3. Hasil Belajar Siswa Pra Penelitian

\begin{tabular}{|c|c|c|c|}
\hline Kategori & \multicolumn{2}{|c|}{ Pre-test } & \multirow{2}{*}{ Ket. } \\
\cline { 2 - 3 } Nilai & $\begin{array}{c}\text { Fre- } \\
\text { kuensi }\end{array}$ & $\begin{array}{c}\text { Persen } \\
\text {-tase }\end{array}$ & \\
\hline$>75$ & 3 & $12,5 \%$ & Tuntas \\
\hline$\leq 74$ & 21 & $87,5 \%$ & $\begin{array}{c}\text { Tidak } \\
\text { Tuntas }\end{array}$ \\
\hline $\begin{array}{c}\text { Rata-rata } \\
\text { nilai }\end{array}$ & 54,17 & - & - \\
\hline
\end{tabular}

Berdasarkan data tersebut dapat diketahui bahwa masih terdapat 21 siswa yang belum mencapai KKM. Nilai rata-rata siswa masih kurang baik yakni sebesar 54,17. Hal ini menunjukkan bahwa Hasil Belajar siswa masih tergolong rendah. Berdasarkan data yang diperoleh hasil belajar siswa masih tergolong rendah. Nilai rata-rata ulangan harian siswa belum mencapai KKM yang ditetapkan oleh sekolah. Nilai rata-rata Kelas X Akuntansi 3 pada UH mata pelajaran Akuntansi Dasar tidak mencapai KKM yang ditetapkan sebesar 75. Jika dilihat lebih detail pada nilai UH dari 26 jumlah keseluruhan siswa hanya 8 siswa yang telah mencapai KKM atau dengan kata lain hanya sebesar $30,8 \%$ siswa yang telah mencapai KKM. Berdasarkan data tersebut dapat disimpulkan terdapat permasalahan pada Kelas X Akuntansi 3 pada mata pelajaran Akuntansi Dasar yakni Hasil Belajar yang masih tergolong rendah.

Berdasarkan hasil wawancara yang dilakukan pada 9 Januari 2019, diketahui bahwa SMK Koperasi Yogyakarta menyediakan fasilitas-fasilitas yang dapat menunjang proses pembelajaran. Terdapat LCD dan proyektor di setiap kelas. SMK Koperasi Yogyakarta juga menyediakan fasilitas wifi yang dapat diakses oleh seluruh siswa dan guru. Sebagian besar guru telah memanfaatkan fasilitas yang disediakan oleh sekolah yaitu LCD dan proyektor dengan menggunakan media powerpoint.

Karakteristik siswa kelas X Akuntansi 3 yaitu senang bermain game pada saat pembelajaran berlangsung. Hal ini terlihat ketika pembelajaran di kelas sedang 
berlangsung siswa nampak sibuk bermain game menggunakan gadget. Selain itu siswa juga lebih senang bekerja secara berkelompok ketika guru memberikan tugas. Hal ini terlihat ketika guru memberikan tugas, siswa meminta kepada guru agar dikerjakan secara berkelompok dan mengeluh ketika diberikan tugas mandiri. Oleh karena itu diperlukan model pembelajaran yang berisi permainan atau game dan dapat dikerjakan secara berkelompok. Fasilitas yang tersedia di kelas X Akuntansi 3 SMK Koperasi Yogyakarta cukup lengkap. Terdapat fasilitas meja, kursi, papan tulis, LCD, proyektor, dan wifi.

Berdasarkan karakteristik siswa dan fasilitas yang terdapat di kelas X Akuntansi 3 SMK Koperasi Yogyakarta, dibutuhkan model pembelajaran Gamifikasi. Gamifikasi merupakan penerapan unsur-unsur game ke dalam konteks non-game untuk menyelesaikan sebuah permasalahan. Model pembelajaran Gamifikasi terdiri atas beberapa level yang harus dilalui siswa, sehingga siswa akan terpacu untuk terus mengikuti proses pembelajaran namun dengan cara yang menyenangkan. Gamifikasi dalam proses pembelajaran dapat meningkatkan antusiasme dan keterlibatan siswa.

Penerapan Gamifikasi dapat dilakukan dengan menggunakan suatu media, salah satunya adalah Kahoot. Media Kahoot sesuai digunakan dengan model pembelajaran Gamifikasi karena Media Kahoot memiliki unsur-unsur game di dalamnya. Media Kahoot juga sesuai dengan karakteristik yang ada pada Gamifikasi.

Menurut laman kahoot.com, Kahoot adalah platform pembelajaran berbasis permainan yang memudahkan untuk membuat, berbagi, dan bermain game belajar yang menyenangkan atau kuis trivia dalam hitungan menit. Kahoot merupakan laman yang menyediakan pembelajaran berbasis game yang dapat diakses secara gratis bagi siswa maupun guru. Kahoot juga dapat digunakan melalui aplikasi yang dapat diunduh melalui Play Store untuk gadget berbasis Android. Kahoot dapat digunakan dengan mudah sebagai media pembelajaran oleh guru. Kahoot memiliki keunggulan di mana siswa dituntut untuk dapat mengerjakan soal secara cepat dan tepat dengan waktu yang terbatas. Pembelajaran menggunakan Kahoot dapat menarik perhatian siswa, didukung dengan adanya tampilan visual yang berwarna dan musik yang menambah suasana untuk berkompetisi dan dapat menjadi solusi permasalahan yang terdapat pada peserta didik yakni Aktivitas Belajar, Motivasi Belajar dan Hasil Belajar.

Berdasarkan latar belakang masalah yang telah diuraikan di atas, peneliti akan melakukan penelitian dengan judul: "Implementasi Gamifikasi Berbantu Media Kahoot untuk Meningkatkan Aktivitas Belajar, Motivasi Belajar, dan Hasil Belajar Jurnal Penyesuaian Siswa Kelas X Akuntansi 3 di SMK Koperasi Yogyakarta Tahun Ajaran 2018/2019”.

\section{METODE PENELITIAN}

\section{Jenis Penelitian}

Penelitian ini menggunakan jenis Penelitian Tindakan Kelas (PTK).

\section{Waktu dan Tempat Penelitian}

Penelitian ini dilaksanakan di kelas $\mathrm{X}$ Akuntansi 3 SMK Koperasi Yogyakarta Tahun Ajaran 2018/2019 yang beralamatkan di Jalan Kapas I/5, Yogyakarta. Penelitian dilakukan dengan 3 tahap yakni persiapan, penelitian, dan pelaporan. Tahap persiapan dilakukan pada bulan Januari-Februari 2019. Tahap penelitian dilaksanakan pada bulan Maret. Tahap pelaporan dilaksanakan pada bulan April-Mei 2019.

\section{Subjek dan Objek Penelitian}

Subjek penelitian ini adalah Siswa Kelas X Akuntansi 3 SMK Koperasi Yogyakarta Tahun Ajaran 2018/2019 yang berjumlah 26 siswa. Sedangkan objek dalam penelitian ini adalah Aktivitas Belajar, Motivasi Belajar, dan Hasil Belajar Jurnal Penyesuaian Siswa Kelas X Akuntansi 3 di SMK Koperasi Yogyakarta Tahun Ajaran 2018/2019 pada 
pembelajaran Akuntansi Dasar kompetensi dasar Jurnal Penyesuaian melalui Penerapan Gamifikasi Berbantu Media Kahoot.

\section{Prosedur}

Penelitian tindakan kelas ini menggunakan model Kemmis dan Mc. Taggart dengan 2 siklus. Masing-masing siklus memiliki 4 tahap dalam pelaksanaannya yakni: perencanaan, tindakan, observasi, dan refleksi. Adapun prosedur pelaksanaan penelitian ini adalah sebagai berikut:

\section{Siklus I}

a. Perencanaan

Pada tahap ini, peneliti menyusun rencana yang akan dilaksanakan dalam penelitian, yaitu: menyusun Rencana Pelaksanaan Pembelajaran (RPP), menyusun instrumen penelitian, menyusun materi, menyusun soal, menyiapkan daftar kelompok, menyiapkan hadiah, menyiapkan catatan lapangan, dan berkonsultasi dengan guru.

b. Tindakan

Pada tahap ini, pelaksanaan pembelajaran dilakukan sesuai dengan langkah-langkah yang telah disusun dalam RPP. Pelaksanaan pembelajaran dilakukan dalam 2 siklus yang terdiri atas kegiatan pembuka, kegiatan inti, dan kegiatan penutup. Langkah-langkah pada siklus I antara lain:

1) Kegiatan pembuka: guru membuka pelajaran dengan salam, berdoa, dan menyanyikan lagu Indonesia Raya, guru melakukan presensi kehadiran siswa, guru menyampaikan tujuan pembelajaran mengenai Jurnal Penyesuaian dan memotivasi siswa, guru membagikan soal pre-test yang dikerjakan siswa secara individu.

2) Kegiatan inti: guru membagi siswa ke dalam 8 kelompok heterogen berdasarkan kemampuan siswa. Kelompok heterogen ini dilihat berdasarkan aktivitas, motivasi, dan hasil belajar siswa; guru mempresentasikan materi mengenai Jurnal Penyesuaian; guru menyampaikan aturan bermain dan tahapan yang harus dilalui oleh siswa untuk mengerjakan kuis Kahoot secara berkelompok; guru memberikan soal yang harus dikerjakan oleh kelompok. Soal tersebut yang akan menjadi bahan dalam permainan Kahoot. Guru membimbing kegiatan belajar siswa dalam kelompok; siswa menyiapkan gadget yang dapat terkoneksi dengan internet, kemudian guru memberikan akses link kepada siswa untuk masuk pada laman Kahoot yang digunakan untuk bermain; siswa mulai mengerjakan soal pada Kahoot Level 1 (Silver Zone) dengan tingkat kesulitan rendah. Siswa diminta untuk dapat mengerjakan minimal 4 dari 5 soal dengan benar. Siswa yang memenuhi kriteria tersebut akan melaju pada Level 2 (Gold Zone). Siswa yang tidak memenuhi kriteria akan mengerjakan tugas perbaikan; guru mengunduh hasil poin yang diperoleh setiap kelompok kemudian mengumumkan kelompok yang melaju pada Level 2 dan kelompok yang harus mengerjakan tugas perbaikan; kelompok yang dinyatakan lolos kemudian mengerjakan kuis Kahoot Level 2. Sedangkan kelompok yang dinyatakan gugur menerjakan tugas perbaikan; guru mengumpulkan hasil tugas perbaikan dan mengunduh hasil poin kelompok pada Level 2; guru memberikan reward kepada 1 kelompok dengan poin tertinggi; siswa mengerjakan soal post-test secara individu.

3) Kegiatan penutup: guru bersama siswa menyimpulkan tentang materi yang telah dipelajari; guru menyampaikan materi pada pertemuan selanjutnya dan meminta 


\section{c. Observasi}

siswa untuk mempelajarinya di rumah; guru menutup pelajaran dengan berdoa dan salam.

Kegiatan observasi dilaksanakan selama proses pembelajaran berlangsung. Observer dalam penelitian ini berjumlah 5 orang yang terdiri dari peneliti dan dibantu dengan 4 observer lain untuk mengamati aktivitas belajar siswa selama pembelajaran berlangsung. Observasi dilakukan menggunakan Lembar Observasi Aktivitas Belajar yang terdiri atas 6 indikator.

d. Refleksi

Pada tahap refleksi, dilakukan evaluasi oleh peneliti dan observer bersama dengan guru mengenai proses pembelajaran yang telah berlangsung. Guru memberikan pendapat dan saran atas pelaksanaan pembelajaran. Hasil evaluasi yang didapatkan menjadi referensi untuk perbaikan pada proses pembelajaran di siklus selanjutnya.

\section{Siklus II}

Pelaksanaan siklus II dilakukan hampir sama dengan siklus I. Perbedaan yang terjadi antara siklus I dan siklus II adalah adanya perbaikan yang telah dievaluasi pada siklus I yang diterapkan pada siklus II. Apabila dengan adanya pelaksanaan pada kedua siklus masih dirasa perlu perbaikan, maka akan dilaksanakan siklus III.

\section{Data, Intrumen, dan Teknik Pengum- pulan}

a. Data

Data yang dikumpulkan dalam penelitian ini menggunakan dokumen berupa data sekunder nilai siswa kelas $\mathrm{X}$ Akuntansi 3 SMK Koperasi Yogyakarta Tahun Ajaran 2018/2019. Data yang diperoleh melalui dokumentasi adalah data nilai ulangan harian siswa yang kemudian digunakan untuk membagi siswa menjadi berkelompok.
Penelitian ini mengumpulkan data melalui lembar observasi. Data yang diperoleh dari lembar observasi adalah data Aktivitas Belajar. Peneliti berkolaborasi dengan 4 orang observer untuk mengukur Aktivitas Belajar siswa. Peneliti dan observer sudah menyamakan persepsi sebelum pembelajaran berlangsung mengenai instrumen observasi, sehingga tidak terjadi perbedaan persepsi.

Pengumpulan data Motivasi Belajar diperoleh melalui instrumen berupa angket. Angket yang digunakan merupakan angket tertutup dengan 4 alternatif jawaban. Siswa diminta untuk memberikan tanda checklist pada kolom yang telah disediakan pada samping pernyataan yang diberikan.

Pengumpulan data melalui tes tertulis dilakukan untuk memperoleh data Hasil Belajar. Tes dilakukan sebanyak dua kali pada setiap siklus, yaitu pre-test dan post-test yang dikerjakan secara individu. Tes tertulis yang diberikan berupa pilihan ganda.

b. Teknik Analisis Data

Teknik analisis data dalam penelitian ini menggunakan teknik analisis deskriptif kuantitatif dengan persentase. Data yang diperoleh dan dianalisis pada penelitian ini adalah data kuantitatif dari hasil Lembar Observasi Aktivitas Belajar, Angket Motivasi Belajar, dan Tes Tertulis Hasil Belajar mata pelajaran Akuntansi Dasar Kelas X Akuntansi 3 SMK Koperasi Yogyakarta. Teknik analisis data yang digunakan adalah sebagai berikut:

1) Teknik analisis presentase Aktivitas

Belajar

$\%$ skor aktivitas belajar $=$

$\frac{\text { skor total yang diperoleh }}{\text { skor maksimal }} \times 100 \%$

Kualifikasi hasil skor Aktivitas

Belajar adalah sebagai berikut:

$85,01 \%-100,00 \% \quad$ Sangat tinggi

$70,01 \%-85,00 \% \quad$ Tinggi 


$$
\begin{array}{ll}
50,01 \%-70,00 \% & \text { Sedang } \\
01,00 \%-50,00 \% & \text { Rendah }
\end{array}
$$

(Akbar, 2013: 157)

2) Teknik analisis presentase Motivasi

Belajar

$\%$ skor motivasi belajar

$=\frac{\text { skor total yang diperoleh }}{\text { skor maksimal }} \times 100 \%$

Kualifikasi hasil skor Motivasi Belajar adalah sebagai berikut:

$\begin{array}{ll}85,01 \%-100,00 \% & \text { Sangat tinggi } \\ 70,01 \%-85,00 \% & \text { Tinggi } \\ 50,01 \%-70,00 \% & \text { Sedang } \\ 01,00 \%-50,00 \% & \text { Rendah }\end{array}$

(Akbar, 2013: 157)

3) Teknik analisis Hasil Belajar

a. Mean (nilai rata-rata)

$\mathrm{Me}=\frac{\sum X i}{n}$

Keterangan:

$\mathrm{Me}=$ Mean (rata-rata)

$\sum \mathrm{x}_{\mathrm{i}}=$ jumlah nilai $\mathrm{x}$ ke I sampai ke $\mathrm{n}$

$\mathrm{N}=$ jumlah individu

(Sugiyono, 2012: 49)

b. Presentase ketuntasan Hasil Belajar

$\%$ ketuntasan hasil belajar

$$
\begin{aligned}
&= \frac{\text { jumlah siswa tuntas }}{\text { jumlah seluruh siswa }} \times 100 \% \\
& \mathrm{X}=\text { Nilai rata-rata, } \\
& \sum \mathrm{x}=\text { Jumlah nilai, } \\
& \mathrm{N}=\text { Jumlah subjek }
\end{aligned}
$$

\section{HASIL PENELITIAN DAN PEMBA- HASAN \\ Peningkatan Aktivitas Belajar}

Hasil penelitian menunjukkan bahwa model pembelajaran Gamifikasi Berbantu Media Kahoot dapat meningkatkan Aktivitas Belajar. Peningkatan tersebut dapat dilihat dari perhitungan pada lembar observasi. Data yang diperoleh dari lembar observasi dihitung persentase per indikator Aktivitas Belajar dan dihitung skor rata-rata Aktivitas Belajar yang dapat dicapai. Perolehan skor rata-rata pada pra penelitian dan tiap siklus dapat dilihat pada tabel sebagai berikut.
Tabel 4. Skor Rata-rata Aktivitas Belajar

\begin{tabular}{|l|l|c|l|}
\hline No & Keterangan & Skor & Kategori \\
\hline 1 & Pra Penelitian & 12,29 & Rendah \\
\hline 2 & Siklus I & 15,52 & Sedang \\
\hline 3 & Siklus II & 18,96 & Baik \\
\hline
\end{tabular}

Hasil yang diperoleh pada tiap siklus dibandingkan untuk melihat persentase peningkatan Aktivitas Belajar. Berdasarkan tabel 4 di atas dapat ditunjukkan secara lebih rinci perolehan skor per indikator pada siklus I dan siklus II dalam persentase. Persentase peningkatan Aktivitas Belajar tersebut dapat dilihat pada tabel berikut.

Tabel 5. Persentase Aktivitas Belajar Siswa

\begin{tabular}{|l|c|c|r|}
\hline $\begin{array}{c}\text { Indi- } \\
\text { kator }\end{array}$ & $\begin{array}{c}\text { Siklus } \\
\text { I }\end{array}$ & $\begin{array}{c}\text { Siklus } \\
\text { II }\end{array}$ & $\begin{array}{c}\text { Pening- } \\
\text { katan }\end{array}$ \\
\hline 1 & $82,14 \%$ & $83,70 \%$ & $1,55 \%$ \\
\hline 2 & $42,86 \%$ & $76,09 \%$ & $32,04 \%$ \\
\hline 3 & $64,29 \%$ & $75,00 \%$ & $9,52 \%$ \\
\hline 4 & $54,76 \%$ & $77,17 \%$ & $22,41 \%$ \\
\hline 5 & $57,14 \%$ & $76,09 \%$ & $18,94 \%$ \\
\hline 6 & $84,52 \%$ & $85,87 \%$ & $1,35 \%$ \\
\hline $\begin{array}{l}\text { Rata- } \\
\text { rata }\end{array}$ & $64,68 \%$ & $78,99 \%$ & $14,30 \%$ \\
\hline
\end{tabular}

Berdasarkan tabel 5 dapat dilihat bahwa indikator keberhasilan penelitian telah dicapai pada siklus II. Aktivitas Belajar dari siklus I ke siklus II meningkat sebesar $14,30 \%$. Peningkatan tertinggi terjadi pada indikator bertanya pada guru atau teman yakni sebesar 20,24\%. Hal ini disebabkan karena siswa lebih terpacu dan lebih atusias dalam mengikuti proses pembelajaran. Peningkatan terendah terjadi pada indikator mengerjakan tes dengan kemampuan sendiri yakni sebesar 1,35\%. Hal ini dikarenakan siswa mengerjakan soal yang diberikan oleh guru secara berkelompok, sehingga siswa mengkolaborasikan kemampuannya dengan teman satu kelompoknya untuk mengerjakan soal yang diberikan.

Sejalan dengan yang dilakukan Papp (2017) menyebutkan bahwa Gamifikasi dapat meningkatkan motivasi dan 
keterlibatan siswa. Reichelt (2015) menyebutkan bahwa penerapan Gamifikasi dapat memotivasi, melibatkan, dan berpotensi meningkatkan prestasi siswa jika diterapkan dengan benar.

\section{Peningkatan Motivasi Belajar}

Peningkatan Motivasi Belajar diukur dengan menggunakan instrumen Angket Motivasi Belajar. Hasil penelitian menunjukkan bahwa dengan diterapkannya Gamifikasi Berbantu Media Kahoot dapat meningkatkan Motivasi Belajar. Peningkatan Motivasi Belajar dilihat dari perhitungan angket. Data yang diperoleh dari angket dihitung skor rata-rata per indikator Motivasi Belajar dan dihitung skor rata-rata Motivasi Belajar. Hasil yang diperoleh pada pra penelitian dan tiap siklus akan dibandingkan untuk melihat skor peningkatan Motivasi Belajar. Perolehan skor rata-rata pada pra penelitian dan tiap siklus dapat dilihat pada tabel berikut.

Tabel 6. Skor Rata-rata Motivasi Belajar

\begin{tabular}{|l|l|c|l|}
\hline No & Keterangan & Skor & Kategori \\
\hline 1 & Pra Penelitian & 61,69 & Rendah \\
\hline 2 & Siklus I & 63,76 & Sedang \\
\hline 3 & Siklus II & 69,70 & Baik \\
\hline
\end{tabular}

Berdasarkan perolehan skor pada tabel 6 di atas, secara lebih rinci persentase peningkatan Motivasi Belajar pada pra penelitian dan masing-masing siklus dapat dilihat sebagai berikut.

Tabel 7. Persentase Motivasi Belajar

\begin{tabular}{|l|c|r|r|r|}
\hline $\begin{array}{c}\text { Indi- } \\
\text { kator }\end{array}$ & $\begin{array}{c}\text { Pra } \\
\text { Peneli } \\
\text {-tian } \\
(\boldsymbol{\%})\end{array}$ & $\begin{array}{c}\text { Siklus } \\
\text { I (\%) }\end{array}$ & $\begin{array}{c}\text { Siklus } \\
\text { II } \\
(\%)\end{array}$ & $\begin{array}{c}\text { Pening } \\
\text {-katan } \\
(\%)\end{array}$ \\
\hline 1 & 70,57 & 72,02 & 79,35 & 8,78 \\
\hline 2 & 69,53 & 72,92 & 80,16 & 10,63 \\
\hline 3 & 69,17 & 72,62 & 79,57 & 10,40 \\
\hline 4 & 67,19 & 72,02 & 78,26 & 11,09 \\
\hline 5 & 71,35 & 73,21 & 78,80 & 7,45 \\
\hline 6 & 71,45 & 72,14 & 78,48 & 7,03 \\
\hline
\end{tabular}

\begin{tabular}{|l|l|l|l|l|}
\hline $\begin{array}{l}\text { Rata- } \\
\text { rata }\end{array}$ & 69,88 & 72,49 & 79,10 & 9,22 \\
\hline
\end{tabular}

Berdasarkan tabel 7 dapat dilihat bahwa indikator keberhasilan penelitian telah dicapai pada siklus II. Motivasi Belajar dari pra penelitian ke siklus I meningkat sebesar 2,49\%, kemudian meningkat kembali pada siklus II sebesar 6,61\%. Peningkatan tertinggi terjadi pada indikator lebih senang bekerja secara mandiri yakni sebesar $11,09 \%$. Hal ini terjadi karena siswa merasa lebih percaya diri dalam mengerjakan soal yang diberikan oleh guru. Peningkatan terendah terjadi pada indikator memiliki pendapat yang kuat yakni sebesar 7,03\%. Hal ini disebabkan karena siswa melakukan proses pembelajaran secara berkelompok dengan berdiskusi, sehingga siswa akan mendiskusikan pendapatnya sesuai dengan kemampuan kelompok.

Hasil penelitian ini sesuai dengan penelitian yang telah dilakukan oleh Sagoro (2016) bahwa pendekatan gamifikasi dapat menambah motivasi untuk belajar. Lister (2015) bahwa penyertaan unsur Gamifikasi seperti poin, lencana, prestasi, dan tingkat (level) menghasilkan efek positif pada motivasi dan meningkatkan prestasi belajar siswa pasca sekolah menengah. Reichelt (2015) menyebutkan bahwa penerapan Gamifikasi dapat memotivasi, melibatkan, dan berpotensi meningkatkan prestasi siswa jika diterapkan dengan benar.

\section{Peningkatan Hasil Belajar}

Peningkatan Hasil Belajar diukur menggunakan instrumen berupa soal tes Hasil Belajar. Soal tes berbentuk pilihan ganda yang digunakan dalam pra penelitian, pre-test dan post-test pada siklus I maupun siklus II sesuai dengan materi pembelajaran pada setiap siklus. Hasil penelitian menunjukkan bahwa dengan penerapan Gamifikasi Berbantu Media Kahoot, mampu meningkatkan Hasil Belajar. Peningkatan Hasil Belajar dilihat dengan membandingkan rata-rata Hasil Belajar dan persentase ketuntasan belajar siswa pada pra 
penelitian dan setiap siklus. Peningkatan Hasil Belajar dapat dilihat pada tabel berikut.

Tabel 8. Peningkatan Hasil Belajar

\begin{tabular}{|l|c|c|c|}
\hline & $\begin{array}{c}\text { Pra } \\
\text { Penelitian }\end{array}$ & $\begin{array}{c}\text { Siklus } \\
\text { I }\end{array}$ & $\begin{array}{c}\text { Siklus } \\
\text { II }\end{array}$ \\
\hline $\begin{array}{l}\text { Rata-rata } \\
\begin{array}{l}\text { Hasil } \\
\text { Belajar }\end{array}\end{array}$ & 54,17 & 73,33 & 81,30 \\
\hline $\begin{array}{l}\text { Ketuntasan } \\
\text { Belajar (\%) }\end{array}$ & 12,50 & 61,90 & 82,61 \\
\hline
\end{tabular}

Berdasarkan tabel 8 dapat dilihat bahwa indkator keberhasilan penelitian telah dicapai pada siklus II yakni sebesar $82,61 \%$. Rata-rata Hasil Belajar dari pra penelitian ke siklus I meningkat sebesar 19,16, kemudian meningkat kembali pada siklus II sebesar 7,97. Persentase ketuntasan belajar dari pra penelitian ke siklus I meningkat sebesar $49,40 \%$, kemudian meningkat kembali pada siklus II sebesar $20,69 \%$.

Sejalan dengan penelitian yang dilakukan oleh Barata, Gama, Jorge, et al (2013) menunjukkan bahwa gamifikasi dapat digunakan untuk meningkatkan partisipasi dan hasil belajar siswa. Wastari (2018) mengemukakan bahwa Gamifikasi dapat meningkatkan Hasil belajar Jurnal Penyesuaian siswa. Reichelt (2015) menyebutkan bahwa penerapan Gamifikasi dapat memotivasi, melibatkan, dan berpotensi meningkatkan prestasi siswa jika diterapkan dengan benar.

Hasil penelitian ini menunjukkan bahwa implementasi Gamifikasi Berbantu Media Kahoot dapat meningkatkan Aktivitas Belajar, Motivasi Belajar, dan Hasil Belajar Jurnal Penyesuaian Siswa Kelas X Akuntansi 3 SMK Koperasi Yogyakarta Tahun Ajaran 2018/2019. Hal ini menunjukkan bahwa dengan adanya perbaikan pada model pembelajaran, Aktivitas Belajar, Motivasi Belajar, dan Hasil Belajar siswa dapat meningkat. Model pembelajaran Gamifikasi ini dapat diimplementasikan kembali pada mata pelajaran Akuntansi Dasar dengan adanya modifikasi maupun tidak.

\section{SIMPULAN DAN SARAN \\ Simpulan}

Berdasarkan hasil penelitian dan pembahasan maka dapat disimpulkan bahwa:

1. Impelementasi model pembelajaran Gamifikasi Berbantu Media Kahoot dapat meningkatkan Aktivitas Belajar Siswa Kelas X Akuntansi 3 SMK Koperasi Yogyakarta Tahun Ajaran 2018/2019. Hal ini dibuktikan dengan adanya peningkatan persentase Aktivitas Belajar pada siklus I sebesar 64,68\%, sedangkan persentase Aktivitas Belajar pada siklus II sebesar 78,99\%. Berdasarkan persentase Aktivitas Belajar yang telah dipaparkan, disimpulkan bahwa Aktivitas Belajar meningkat sebesar $14,30 \%$.

2. Implementasi model pembelajaran Gamifikasi Berbantu Media Kahoot dapat meningkatkan Motivasi Belajar Siswa Kelas X Akuntansi 3 SMK Koperasi Yogyakarta Tahun Ajaran 2018/2019. Hal ini dibuktikan dengan persentase Motivasi Belajar pada pra penelitian sebesar $69,88 \%$, persentase Motivasi Belajar pada siklus I sebesar $72,49 \%$, sedangkan persentase Motivasi Belajar pada siklus II sebesar $79,10 \%$. Berdasarkan persentase Motivasi Belajar yang telah dipaparkan, disimpulkan bahwa Motivasi Belajar dari pra penelitian ke siklus II meningkat sebesar $9,22 \%$.

3. Implementasi model pembelajaran Gamifikasi Berbantu Media Kahoot dapat meningkatkan Hasil Belajar Jurnal Penyesuaian Siswa Kelas X Akuntansi 3 SMK Koperasi Yogyakarta Tahun Ajaran 2018/2019. Peningkatan ini dilihat dari perbandingan persentase nilai rata-rata post-test pada masingmasing siklus, Hasil Belajar Jurnal Penyesuaian Siswa pada nilai rata-rata pra penelitian sebesar 54,17, Hasil 
Belajar Jurnal Penyesuaian pada nilai rata-rata post-test siklus I sebesar 73,33 sedangkan Hasil Belajar Jurnal Penyesuaian Siswa pada nilai rata-rata post-test siklus II sebesar 81,30. Presentase ketuntasan belajar pada pra penelitian $12,5 \%$, persentase ketuntasan belajar pada siklus I sebesar 61,90\%, sedangkan persentase ketuntasan belajar pada siklus II sebesar $82,61 \%$. Berdasarkan hasil pra penelitian dan post-test siklus II dapat disimpulkan bahwa Hasil Belajar Jurnal Penyesuaian Siswa mengalami peningkatan sebesar 27,13 dan ketuntasan Hasil Belajar Jurnal Penyesuaian Siswa meningkat sebesar $70,11 \%$.

\section{Saran}

Berdasarkan penelitian pengembangan yang dilakukan, peneliti memberikan beberapa saran pemanfaatan dan pengembangan media lebih lanjut sebagai berikut:

1. Guru perlu lebih sering memberikan semangat, dukungan, dan motivasi kepada siswa agar siswa lebih bersemangat dalam mengikuti proses pembelajaran.

2. Guru perlu mencoba menggunakan model pembelajaran yang bervariasi agar proses pembelajaran lebih maksimal dan siswa tidak mudah bosan untuk mengikuti proses pembelajaran.

3. Guru perlu menerapkan sistem pemberian reward and punishment kepada siswa agar siswa lebih bersemangat dan termotivasi dalam mengikuti proses pembelajaran.

4. Siswa perlu lebih aktif dalam proses pembelajaran agar dapat lebih memahami materi pelajaran.

5. Siswa perlu meningkatkan semangat dan motivasi belajarnya agar tidak mudah bosan dalam menjalani proses pembelajaran.

6. Siswa perlu lebih giat belajar agar mampu mencapai KKM yang telah ditetapkan sekolah atau bahkan lebih.
7. Untuk penelitian tindakan selanjutnya dapat membahas secara spesifik faktorfaktor mempengaruhi siswa yang kurang aktif dalam pembelajaran, kurang termotivasi, maupun belum mencapai KKM.

\section{DAFTAR PUSTAKA}

Amir, Zubaidah \& Risnawati. (2015). Psikologi Pembelajaran Matematika. Yogyakarta: Aswaja Pressindo.

Arifin, Zainal. (2013). Evaluasi Pembelajaran. Bandung: PT Remaja Rosdakarya.

Arikunto, Suharsimi \& Suhardjono \& Supardi. (2016). Penelitian Tindakan Kelas. Jakarta: PT Bumi Aksara.

Barata, G., Gama, S., Jorge, J., et al. (2013). Improving Participation and Learning with Gamification. Proceedings of the First Internatioal Conference on gameful design, research, and applications.

Cutrl, R., Marim L. R., Cordeiro J. R., et al. (2016). Kahoot, A New and Cheap Way to Get Clasroom-Response Instead of Using Clickers. American Society for Engineering Education.

Dalyono, M. (2009). Psikologi Pendidikan. Jakarta: Rineka Cipta.

Dimyati \& Mudjiono. (2010). Belajar dan Pembelajaran. Jakarta: PT. Rineka Cipta.

Hamalik, Oemar. (2011). Kurikulum dan Pembelajaran. Jakarta: Bumi Aksara.

(2010). Perencanaan Pengajaran Berdasarkan Pendekatan Sistem. Jakarta: Bumi Aksara. (2017). Proses Belajar Mengajar. Jakarta: Bumi Aksara. 
Irwan, Irwan, Luthfi, Zaky F., \& Waldi, Atri. (2019). Efektifitas Penggunaan Kahoot! Untuk meningkatkan Hasil Belajar Siswa. PEDAGOGIA: Jurnal Pendidikan; Volume 8.

Jusuf, Heni. (2016). Penggunaan Gamifikasi dalam Proses Pembelajaran. Universitas Nasional. Jurnal TICOM Vol.5 No.1.

Kapp, Karl M. (2012). The Gamification of Learning and Instruction: Game Based Method and Strategies for Training And Education. Pfeiffer.

Komaidi, Didik. (2011). Panduan Lengkap PTK. Yogyakarta: Sabda Media.

Kompri. (2015). Motivasi Pembelajaran Prespektif Guru dan Siswa. Bandung. PT Rosdakarya.

Kurniasih, Imas \& Sani, Berlin. (2014). Teknik dan Cara Mudah Membuat Penelitian Tindakan Kelas untuk Pengembangan Profesi Guru. Jakarta: Kata Pena.

Licorish, S., George, J., Owen, H., et al. (2017). "Go Kahoot!" Enriching Classroom Engagement, Motivation, and Learning Experience with Games. Proceedings of the 25 International Conference on Computers in Education.

Lime. (2018). Pemanfaatan Media Kahoot pada Proses Pembelajaran Model Kooperatif tipe STAD Ditinjau dari Kerjasama dan Hasil Belajar Siswa Kelas VIII-1 SMP Negeri 5 Yogyakarta Tahun Ajaran 2017/2018. Skripsi. Yogyakarta: FKIP USD.

Lister, Meaghan C. (2015). Gamification: The Effect On Student Motivation and Performance at The Post-Secondary
Level. Issues and Trends in Educational Technology. Vol. 3, No. 2.

Malas, Reem \& Thair Hamtini. (2016). A Gamified e-Learning Design Model to Promote and Improve Learning. International Review on Computers and Software; Volume 11.

Moncada, Susan M. \& Thomas P. Moncada. (2014). Gamification of Learning in Accounting Education. Journal of Higher Education Theory and Pretice, Volume 14.

Mumpuni, Intan P. Penerapan Gamifikasi Pembelajaran Berbantu Aplikasi Powtoon pada Materi Jurnal Penyesuaian untuk Meningkatkan Motivasi Belajar Siswa Kelas X Akuntansi 1 SMKN 1 Tempel Tahun Ajaran 2017/2018. Skripsi. Yogyakarta: FE UNY.

Papp, Teresa. (2017). The Impact of Gamification on Students' Extrinsic and Intrinsic Motivation. International Conference The Future of Education.

Priansa, Donni Juni. (2017). Pengembangan Strategi dan Model Pembelajaran. Bandung: Pustaka Setia.

Purwanto, Ngalim. (2004). Prinsip-prinsip dan Teknik Evaluasi Pengajaran. Bandung: PT. Remaja Rosdakarya.

Reichelt, Annie Lee. (2015). Effects of Gamification: Analyzing Student Achievement, Mistery, and Motivation In Science Classrooms. Paper. Page 149. Montana State University.

Rutkauskiene, D., Maskeliunas, R., Gudoniene, D., et al. (2016). The Gamification Model for E-Learning Participants Engagement. Smart 
Innovation, Systems and Technologies 59.

Sagoro, Endra M. (2016). Keefektifan Pembelajaran Kooperatif Berbasis Gamifikasi Akuntansi pada Mahasiswa Non-Akuntansi. Jurnal Pendidikan Akuntansi Indonesia; Vol.XIV No.2, 63-79.

Sahin, Mehmet Can \& Nihan Arslan Namli. (2016). Gamification and Effect on Students' Science Lesson Achievement. International Journal on New Trends in Education and Their Implications; Volume 7.

Sanjaya, Wina. (2014). Strategi Pembelajaran Berorientasi Standar Proses Pendidikan. Jakarta: Kencana Prenada Media Group.

Sardiman A.M. (2011). Interaksi dan Motivasi Belajar Mengajar. Jakarta: Rajawali.

Slameto. (2010). Belajar dan Faktor-Faktor yang Mempengaruhinya. Jakarta: Rineka Cipta.

Smkn2kuripan. (2017). Cara Memainkan Kahoot-Kuis untuk Pembelajaran di kelas [Bagian 3]. Diunduh tanggal 14 Januari 2019 dari https://www.smkn2kuripan.sch.id/cara -memainkan-kahoot-kuis-untukpembelajaran-di-Kelas-bagian-3/

Srisomboon, Paripas \& Namon Jeerungsuwan. (2015). Gamification Model for Virtual Team Collaborative Learning via Cloud Technology. The Tweifth International Conference on eLearning for Knowledge-Based Society.

Sudjana, Nana. (2014). Penilaian Hasil Proses Belajar Mengajar. Bandung: PT. Remaja Rosdakarya.
Suryabrata, Sumardi. (2006). Psikologi Pendidikan. Jakarta: Remaja Rosdakarya.

Uno, Hamzah B. (2016). Perencanaan Pembelajaran. Jakarta: Bumi Aksara. (2017). Teori Motivasi dan Pengukurannya Analisis di Bidang Pendidikan. Jakarta: Bumi Aksara.

Usman, Moh. U. (2009). Menjadi Guru Profesional. Bandung: Remaja Rosdakarya

Wastari, Dinda A. P. (2018). Penerapan Model Pembelajaran Kooperatif Berbasis Gamifikasi untuk Meningkatkan Hasil Belajar Materi Jurnal Penyesuaian pada Siswa Kelas X Akuntansi G SMK Muhammadiyah 1 Yogyakarta Tahun Ajaran 2017/2018. Skripsi. Yogyakarta: FE UNY.

Wiriaatmadja, Rochiati. (2012). Metode Penelitian Tindakan Kelas. Bandung: PT Remaja Rosdakarya. 